\title{
Warming of waters in an East Greenland fjord prior to glacier retreat: mechanisms and connection to large-scale atmospheric conditions
}

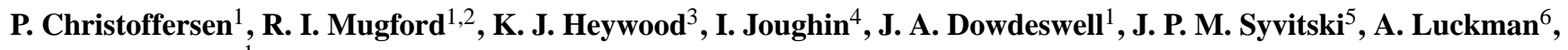 \\ and T. J. Benham ${ }^{1}$ \\ ${ }^{1}$ Scott Polar Research Institute, University of Cambridge, Cambridge, UK \\ ${ }^{2}$ Environmental Systems Science Centre, University of Reading, Reading, UK \\ ${ }^{3}$ School of Environmental Sciences, University of East Anglia, Norwich, UK \\ ${ }^{4}$ Applied Physics Laboratory, University of Washington, Seattle, USA \\ ${ }^{5}$ Institute of Arctic and Alpine Research, University of Colorado, Boulder, USA \\ ${ }^{6}$ School of the Environment and Society, Swansea University, Swansea, UK
}

Received: 19 April 2011 - Published in The Cryosphere Discuss.: 5 May 2011

Revised: 22 July 2011 - Accepted: 2 August 2011 - Published: 9 September 2011

\begin{abstract}
Hydrographic data acquired in Kangerdlugssuaq Fjord and adjacent seas in 1993 and 2004 are used together with reanalysis from the NEMO ocean modelling framework to elucidate water-mass change and ice-ocean-atmosphere interactions in East Greenland. The hydrographic data show that the fjord contains warm subtropical waters and that fjord waters in 2004 were considerably warmer than in 1993 . The ocean reanalysis shows that the warm properties of fjord waters in 2004 are related to a major peak in oceanic shoreward heat flux into a cross-shelf trough on the outer continental shelf. The heat flux into this trough varies according to seasonal exchanges with the atmosphere as well as from deep seasonal intrusions of subtropical waters. Both mechanisms contribute to high (low) shoreward heat flux when winds from the northeast are weak (strong). The combined effect of surface heating and inflow of subtropical waters is seen in the hydrographic data, which were collected after periods when along-shore coastal winds from the north were strong (1993) and weak (2004). The latter data were furthermore acquired during the early phase of a prolonged retreat of Kangerdlugssuaq Glacier. We show that coastal winds vary according to the pressure gradient defined by a semi-permanent atmospheric high-pressure system over Greenland and a persistent atmospheric low situated near Iceland. The magnitude of this pressure gradient is controlled by longitudinal variability in the position of the Icelandic Low.
\end{abstract}

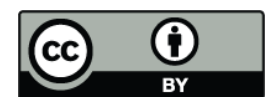

Correspondence to: P. Christoffersen (pc350@cam.ac.uk)

\section{Introduction}

The mass balance of the Greenland Ice Sheet has changed from a state close to balance in the 1980s and 1990s (Rignot et al., 2008; Hanna et al., 2005) to a state where net annual losses exceed $200 \mathrm{Gt} \mathrm{yr}^{-1}$ (Rignot and Kanagaratnam, 2006; Velicogna and Wahr, 2006; Chen et al., 2006; Rignot et al., 2008; van den Broeke et al., 2009). This ice loss is equivalent to a global sea-level rise of $\sim 0.6 \mathrm{~mm} \mathrm{yr}^{-1}$ and there is concern that future losses could accelerate substantially (IPCC, 2007). Up to $2 / 3$ of a total net ice loss of $220 \mathrm{Gt}$ in 2005 was caused by the acceleration of tidewater glaciers (Rignot and Kanagaratnam, 2006). Several large glaciers have subsequently slowed down, most notably Helheim Glacier and Kangerdlugssuaq Glacier (KG) on the east coast (Howat et al., 2007). However, van den Broeke et al. (2009) show that dynamic losses from discharge of ice into fjords still amount to $\sim 50 \%$ of the total net ice loss when the reduced discharges after 2005 are taken into account. In recent years, nearly $75 \%$ of the net annual imbalance from discharge has come from southeast Greenland (van den Broeke et al., 2009) where glacier fluctuations have been large and synchronous (Luckman et al., 2006; Stearns and Hamilton, 2007; Joughin et al., 2008a; Howat et al., 2008). While ice sheet surface melt is known to influence ice flow (Zwally et al., 2002) and cause diurnal fluctuations in flow speed (Shepherd et al., 2009), the effect of surface melt appears limited on interannual time scales (van de Wal et al., 2008; Sundal et al., 2011). The sustained increase in discharge of ice, most significantly

Published by Copernicus Publications on behalf of the European Geosciences Union. 

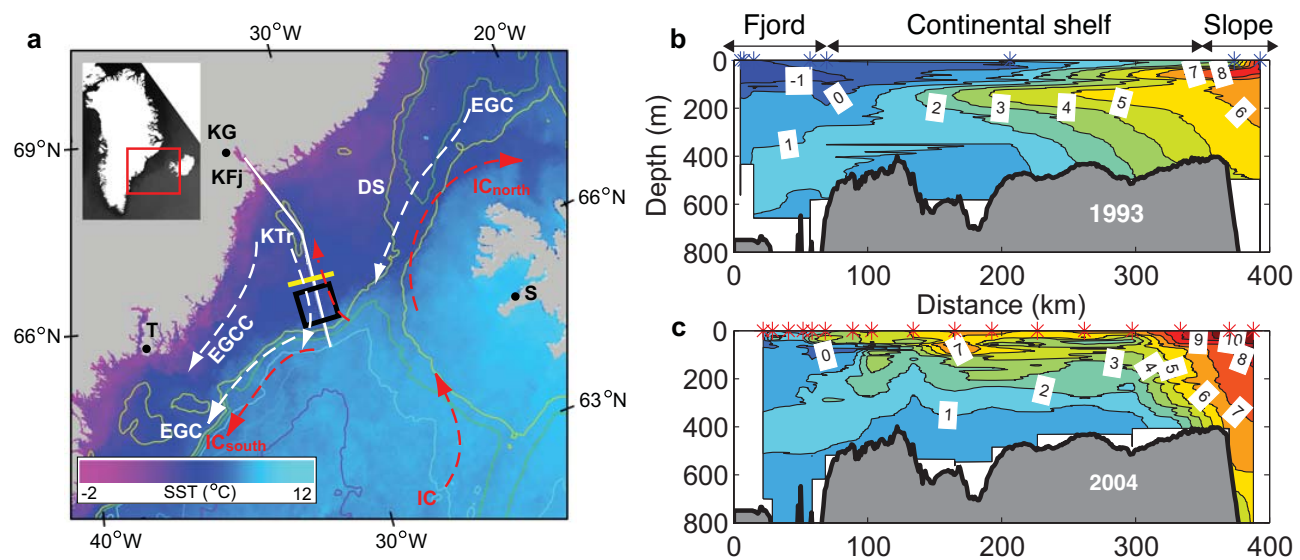

Fig. 1. (a) Map of central East Greenland and regions near Denmark Strait (DS). KG, KFj and KTr mark locations of Kangerdlugssuaq Glacier, Kangerdlugssuaq Fjord and Kangerdlugssuaq Trough. White solid line shows hydrographic transect for the vertical sections shown in (b) (1993) and (c) (2004). Black box represents the area used to compute temperature and salinity at depth. The yellow line is a transect used to calculate variations in oceanic heat flux. Dashed arrows illustrate paths of the Irminger Current (IR), East Greenland Current (EGC) and East Greenland Coastal Current (EGCC). Colours illustrate whether currents are warm (red) or cold (white). Contours mark bathymetry in $500 \mathrm{~m}$ intervals and the background colour scheme shows sea-surface temperature in August 2004 from Oceancolor SST climatology. Black dots mark location of Tasiilaq (T) and Stykkishólmur (S). (b) Vertical section showing potential temperature of water masses in KFj and KTr in September 1993. (c) Same as (b), but for observations in September 2004. The topographic overlay is the observed bathymetry in $\mathrm{KFj}$ and along $\mathrm{KTr}$.

from eastern tidewater glaciers, may therefore be related to oceanic conditions (Sole et al., 2008; Straneo et al., 2010; Seale et al., 2011).

Coastal waters in West Greenland have warmed since 1996 (Holland et al., 2008) and the warming may be related to increased transport of subtropical waters to the Irminger Sea (Falina et al., 2007; Sarafanov et al., 2007, 2009; Yashayaev et al., 2007). The latter occurred when the North Atlantic Oscillation (NAO) switched from a strong phase in 19931995 to a weak state in 1996, resulting in slowdown and contraction of the subpolar North Atlantic gyre (Flatau et al., 2003; Hakkinen and Rhines, 2004). As a consequence, warmer and larger volumes of subtropical waters entered the Irminger Sea and thus the Irminger Current, which splits near Denmark Strait. A small branch flows clockwise around Iceland while the larger branch flows southward along the East Greenland continental shelf edge (Fig. 1).

Although recent studies have suggested a sensitive interaction of the Greenland Ice Sheet with its surrounding seas (Holland et al., 2008; Rignot et al., 2010; Murray et al., 2010), ice-ocean interactions in Greenland remain uncertain and poorly documented. It is not yet clear if recent changes in the flow of tidewater glaciers were caused by increased transport of warm subtropical waters to coastal environments and fjords or by changes in the properties of these waters. The influence of air-sea heat exchange associated with sustained atmospheric warming, e.g. as reported by Box et al. (2009), is also not firmly established.
Here, we use hydrographic data acquired in Kangerdlugssuaq Fjord (KFj) and adjacent seas in 1993 and 2004, together with reanalysis from the Nucleus for European Modelling of the Ocean (NEMO), to establish the connection between ice-ocean interaction in a glaciated fjord and offshore air-sea interactions. The hydrographic datasets are unique in that they were acquired when the NAO was strong (1993) and weak (2004), respectively. The latter data were furthermore acquired during the early stage of the rapid and welldocumented retreat of KG. In 1993, we found cold polar surface water $\left(<0^{\circ} \mathrm{C}\right)$ as well as strongly modified and relatively cold water with subtropical origin $\left(\sim 1^{\circ} \mathrm{C}\right.$ or less). The subtropical waters extended further into the fjord in 2004 and the waters were less modified, warmer $\left(\sim 1.8^{\circ} \mathrm{C}\right.$ or more $)$ and located $\sim 100 \mathrm{~m}$ higher than in 1993, whilst polar surface water was up to $4{ }^{\circ} \mathrm{C}$ warmer than in 1993 .

The reanalysis shows that oceanic heat flux directed towards KFj in 2003-2004 is several times higher than the heat flux of preceding years, and it peaks about one year prior to the abrupt retreat of KG. The heat flux varies according to seasonal heat exchange with the atmosphere as well as from deep seasonal inflows of subtropical waters onto the shelf. Both mechanisms contribute to high (low) shoreward heat flux when winds from the northeast are weak (strong) and warm (cold). The combined effect of surface heating and the deeper inflow of subtropical waters is consistent with the hydrographic data, which was collected after periods when northerly winds were strong (1993) and weak (2004). 


\section{Data and methods}

\subsection{Hydrographic surveys}

Hydrographic data from $\mathrm{KFj}$ and from transects along the submarine trough known as Kangerdlugssuaq trough (KTr) were acquired during 4-16 September 1993 and 1-10 September 2004 (Fig. 1a). A Sea-Bird 19 with conductivity, temperature and depth (CTD) sensor was used in 1993 to derive salinity and potential temperature at five stations along $\mathrm{KTr}$, from the mouth of KFj to the continental shelf break (Fig. 1a), and in three stations located in the central upper part of the fjord near KG (Fig. 3a) (Azetsu-Scott and Tan, 1997). A Sea-Bird CTD sensor was also used in 2004 to derive the salinity and potential temperature of water masses. The difference in station locations in the upper part of $\mathrm{KFj}$ (Fig. 3a) was a result of a high concentration of icebergs produced by KG in July and August 2004, i.e. during the early phase of the prolonged retreat that lasted until March 2005. Salinity and temperature sensors were calibrated prior to data acquisition. Salinity was further calibrated in 2004 using salinity samples collected at each station from the rosette water sampler mounted on the CTD frame. The bathymetry of $\mathrm{KFj}$ and the adjacent East Greenland shelf and its cross-shelf trough (KTr) are from Syvitski et al. (1996) and Dowdeswell et al. (2010).

\subsection{Ocean reanalysis}

The interannual variations of subsurface waters along the East Greenland continental shelf is examined using a 22year-long ocean reanalysis (1987-2008) from the NEMO coupled ocean modelling framework version 2.3 (Madec, 2008). The reanalysis is produced by the OPA9 ocean model and the LIM2.0 sea ice model (Fichefet and Maqueda, 1997; Goosse and Fichefet, 1999) with eddy-permitting $1 / 4$ degree resolution on the tripolar ORCA025 grid (Barnier et al., 2006). The ocean model simulation is referred to as reanalysis (rather than a hindcast) because it assimilates in situ measurements of temperature and salinity. The model has 46 vertical levels with thicknesses ranging from $6 \mathrm{~m}$ at the surface to $250 \mathrm{~m}$ at the ocean floor. The deep (>300 m) bathymetry at $1 / 4$ degree resolution is constructed from the 2-minute ETOPO global bathymetric field from the National Geophysical Data Centre, while shallower regions on continental shelves are approximated with the GEBCO 1-minute bathymetry.

Surface atmospheric forcing for the reanalysis is the DRAKKAR Forcing Set 3 (Brodeau et al., 2010), a hybrid dataset making use of the ERA-40 atmospheric reanalysis, ECWMF operational analyses and the Common Ocean Reference Experiment dataset (Large and Yeager, 2004). The parameter settings of the eddy-permitting $1 / 4$ degree resolution NEMO ocean model are discussed by Barnier et al. (2006) and Penduff et al. (2010).

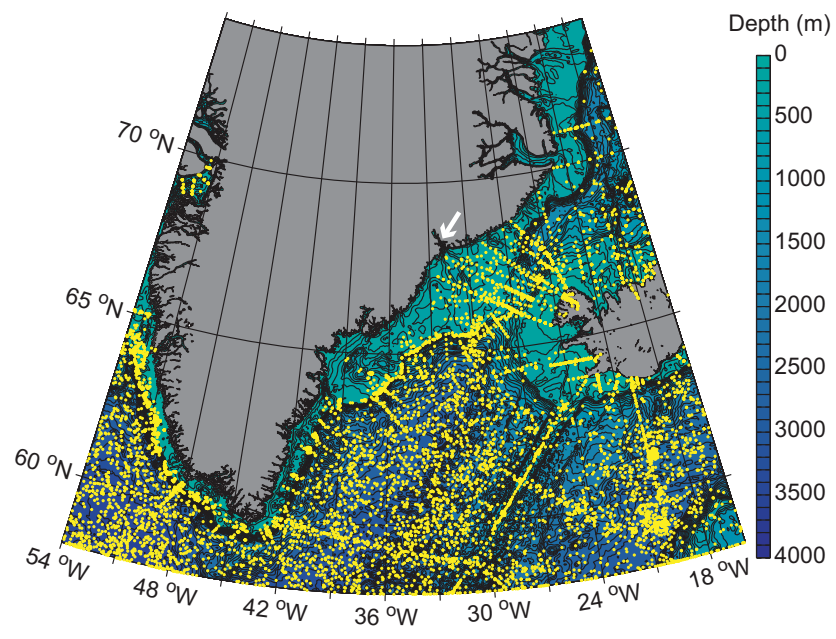

Fig. 2. Map of Greenland and the Irminger Sea with yellow dots showing location of in situ salinity and temperature measurements assimilated in the ocean reanalysis (see text for details). White arrow marks location of $\mathrm{KFj}$ and background colour shows bathymetry of the ocean.

The model experiment used for this analysis is referred to as UR025.1. In situ temperature and salinity observations from the UK Met Office quality controlled ENACT/ENSEMBLES dataset EN3-v1c (which includes data from the World Ocean Database 2005 (www.nodc.noaa.gov/ OC5/WOD05/pr_wod05), the Global Temperature-Salinity Profile Program (http://www.nodc.noaa.gov/GTSPP/) and Argo (http://www.argo.net)) are assimilated using the $\mathrm{S}(\mathrm{T})$ method (Haines et al., 2006). This limits model bias and results in more accurate representation of water mass properties (Gemmell et al., 2008, 2009; Smith et al., 2010). There is a good coverage of temperature and salinity observations from the outer shelf region of southeast Greenland and the Irminger Sea (Fig. 2), making this ocean reanalysis appropriate for the purposes of this study.

\section{Results}

\subsection{Hydrographic observations from $\mathrm{KFj}$ and $\mathrm{KTr}$}

We identify four different water masses with properties similar to those characterised by Rudels et al. (2002) and Sutherland and Pickart (2008). In 1993, Atlantic Water (AW) with potential temperature $\theta>2{ }^{\circ} \mathrm{C}$ and salinity $S \sim 35$ penetrated beneath cold Polar Surface Water (PSW) with $\theta<0{ }^{\circ} \mathrm{C}$ and $S<32$ (Fig. 1b). The densest water on the shelf was Polar Intermediate Water (PIW) with potential density of $\sigma_{\theta}>$ 27.9 compared with $27.55<\sigma_{\theta}<27.75$ for AW and $\sigma_{\theta}<$ 27.7 for PSW. Inside KFj (Fig. 3), we observed cold PSW $\left(\theta \sim-1{ }^{\circ} \mathrm{C}\right)$ in the upper $100 \mathrm{~m}$ while deeper water was the denser PIW (Fig. 3a). Cooled and strongly modified AW water $\left(\sim 1{ }^{\circ} \mathrm{C}\right.$ or less) was located near the fjord mouth at 

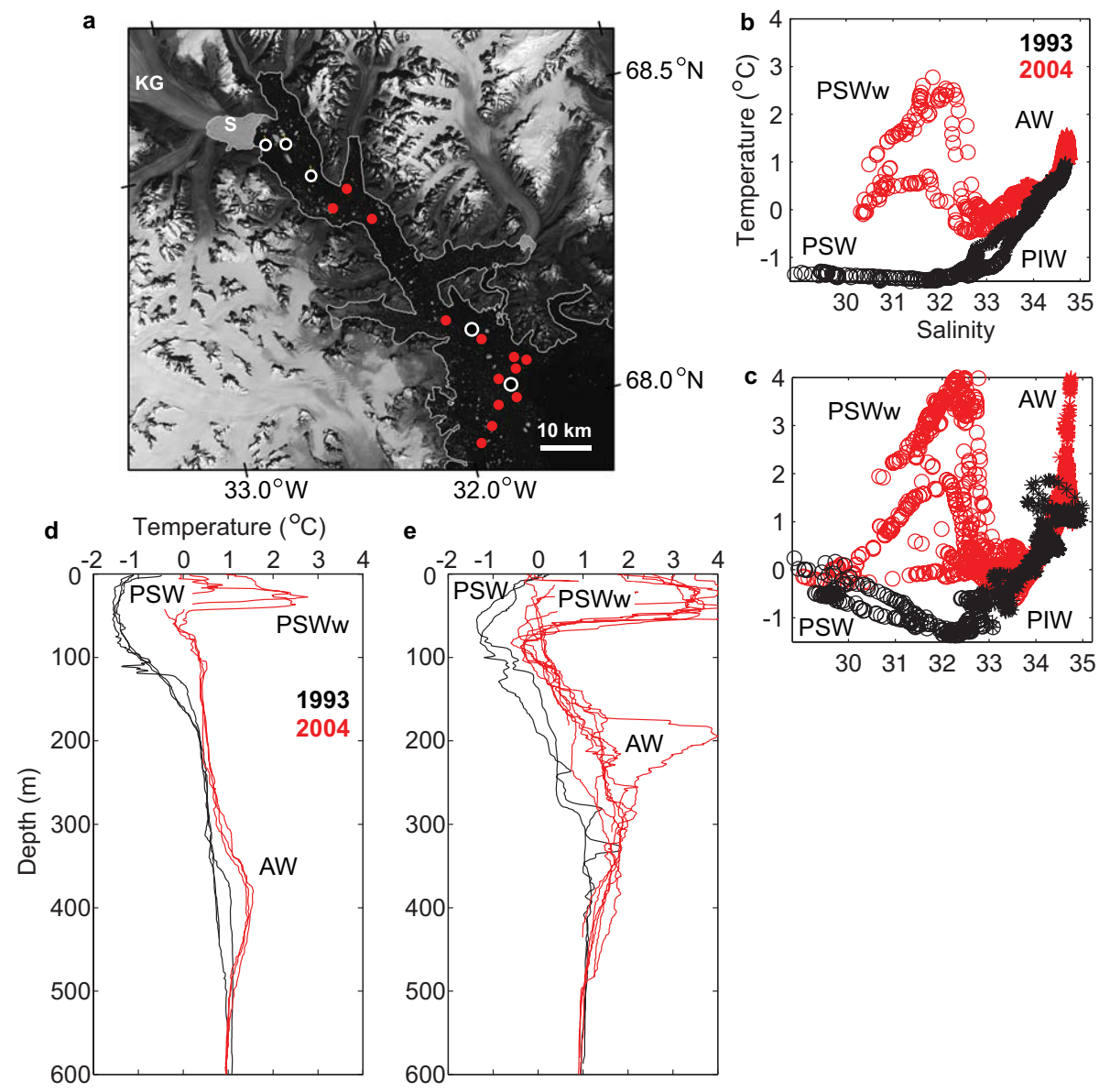

Fig. 3. (a) Landsat image showing KG and KFj on 16 August 2002. White circles show locations of CTD casts in 1993 and red dots show corresponding stations in 2004. (b) Potential temperature and salinity from CTD data acquired in the upper central fjord $\left(68.4^{\circ} \mathrm{N}, 32.2^{\circ} \mathrm{W}\right)$ in 1993 (black) and 2004 (red). Data from 0-100 m are marked open circles and deeper measurements are shown with asterisk. (c) Same as (b) but for data acquired at fjord mouth $\left(68.1^{\circ} \mathrm{N}, 31.9^{\circ} \mathrm{W}\right)$. (d) Potential temperature from CTD casts in upper fjord in 1993 (black) and 2004 (red). (e) Same as (d), but for CTD casts near fjord mouth.

280-590 m depth (Fig. 3c, e) and at depths $>350 \mathrm{~m}$ in the central part of the fjord (Fig. 3b, d). Warm PSW (PSWw) with $\theta>2{ }^{\circ} \mathrm{C}$ and $S<32$ was in 2004 present throughout the 300-km-long shelf (Fig. 1c). The PSWw inside the fjord was up to $\sim 4^{\circ} \mathrm{C}$ warmer than the PSW observed in 1993 (Fig. 3b, d). The temperature of PSWw near the fjord mouth was $>3{ }^{\circ} \mathrm{C}$ in 2004 compared with $<0{ }^{\circ} \mathrm{C}$ for PSW in 1993 (Fig. 3c, e). The AW deep intrusion was in 2004 warmer $\left(\sim 1.8^{\circ} \mathrm{C}\right)$ and located $100 \mathrm{~m}$ higher than in 1993 (Fig. 3d, e).

Figure 4 shows mean annual air temperature in Aputiteq at the southern end of the fjord mouth $\left(67.78^{\circ} \mathrm{N}, 32.30^{\circ} \mathrm{W}\right.$, $25 \mathrm{~m}$ a.s.l). The record shows that air temperatures during the early 2000s were considerably warmer than the 1990s. The mean annual air temperature was $-2.4^{\circ} \mathrm{C}$ in 2004 compared to $-4.4^{\circ} \mathrm{C}$ in 1993 . The mean temperature averaged for summer months only (June-September) was $2.8^{\circ} \mathrm{C}$ in 2004 compared to $0.90^{\circ} \mathrm{C}$ in 1993 . The $\theta-S$ plots in Fig. 3 nonetheless show that properties of PSWw observed in 2004 were influenced by mixing with warm AW in addition to the exchange of heat with the atmosphere. However, with only two snapshots of the subsurface conditions, we cannot firmly establish whether the measured properties represent a significant change or whether they are a result of seasonal or higher frequency variability. The properties of water masses in the intervening period are therefore examined using the ocean reanalysis described in Sect. 2.2. above.

\subsection{Shelf water exchange in ocean reanalysis}

The $\mathrm{KTr}$ is a cross-shelf trough, extending about $300 \mathrm{~km}$ from the fjord mouth to the continental shelf edge. It has a maximum depth of about $600 \mathrm{~m}$ set between shallower banks of about $400 \mathrm{~m}$ water depth (Syvitski et al., 1996; Dowdeswell et al., 2010). The trough is capable of steering waters in the East Greenland and Irminger currents onto the continental shelf, as illustrated in Fig. 1a (Sutherland and Pickart, 2008). Figure 5 shows Hovmøller diagrams of temperature and salinity for water masses flowing into and 


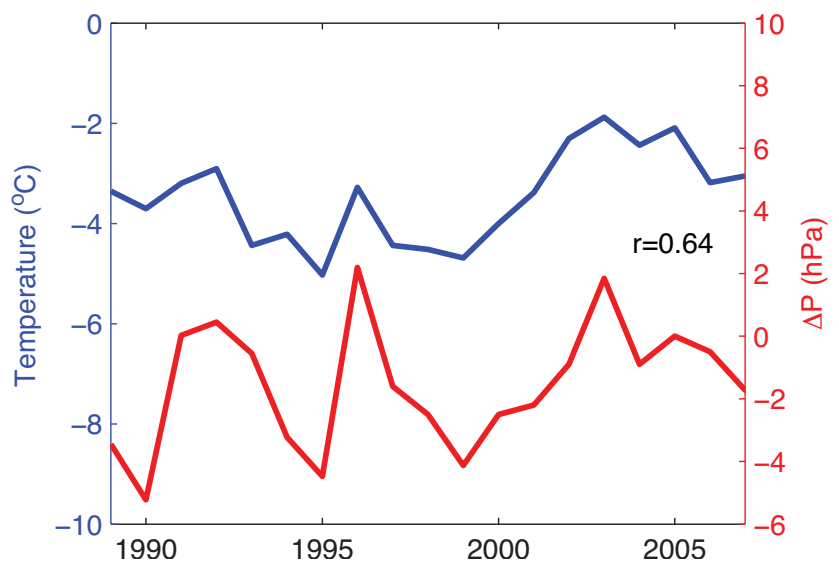

Fig. 4. Plot illustrating connection between mean annual air temperature measured in Aputiteq (blue) and $\Delta P$ (red), which is the mean winter (December-March) difference between atmospheric pressure measured in Stykkishólmur (Iceland) and Tasiilaq (Greenland). See text for details.

out of KTr (see Fig. 2 for location). Seasonal changes are seen at all depths with near-surface temperatures varying between $\sim 0{ }^{\circ} \mathrm{C}$ in winter to $\sim 10^{\circ} \mathrm{C}$ in summer. Decadal averages of temperature (salinity) of surface waters in the upper $100 \mathrm{~m}$ change from $4.5^{\circ} \mathrm{C}(34.54)$ in $1989-1998$ to $5.6^{\circ} \mathrm{C}$ (34.70) in 1999-2008 (Fig. 7a). This trend comprises a gradual rise from $3.3^{\circ} \mathrm{C}(34.38)$ in 1995 to $6.9^{\circ} \mathrm{C}$ (34.87) in 2003.

Temperature profiles for September 1993 and September 2004, as seen in the ocean reanalysis, are plotted in Fig. 6a, b together with temperature profiles from station measurements taken in the same months at nearby locations. The comparison of reanalysis data and observations is favourable in that the former falls within the variability of the latter. The ocean reanalysis profiles are calculated for the box shown in Fig. 6c, which is the same box used to calculate temperature and salinity as shown in Figs. 5 and 7. When observations are averaged across the approximate same area, we find a very good fit between modelled and observed temperature and salinity (Fig. 6d).

The seasonal temperature changes at depths of 400-800 m seen in Fig. 5 are not caused by near-surface variations related to sea ice formation and melt and the exchange of heat with the atmosphere (Fig. 5). The variations are caused instead by movement of water masses onto and off the continental shelf, with temperature and salinity of deep waters co-varying synchronously (Fig. 7a, b). Decadal averages of temperature (salinity) at $400-800 \mathrm{~m}$ rise from $4.1^{\circ} \mathrm{C}(34.98)$ in $1989-1998$ to $4.7^{\circ} \mathrm{C}(35.03)$ in $1999-2008$. The increases in temperature and salinity are higher than the warming $\left(\sim 0.2^{\circ} \mathrm{C}\right)$ and salinification $(\sim 0.022)$ observed in the central Irminger Sea at equivalent depth between 1996 and 2006 (Sarafanov et al., 2007). The difference is related to the variable volume flux of AW into KTr. Notable increase in the inflow of AW occurred in 1991, 1996 and 2001-2005
(Fig. 7a, b), corresponding to years when the NAO was weak. The extended NAO winter index (December-March), which is based on the difference of normalised sea-level pressure between Lisbon (Portugal) and Stykkishólmur (Iceland), is shown in Fig. 7b. The index has a marked similarity to salinity as well as temperature variations at 400-800 m (Fig. 7a). This connection is related to coastal winds, as explained in Sect. 5 below, whilst changing properties of surface water is mainly a result of increased air-sea heat exchange due to atmospheric warming since 1995 (Box et al., 2009). The latter is also seen in the Aputiteq temperature record (Fig. 4). The increased temperatures near the surface as well as depths of 400-800 m cause high heat flux into KTr in 2003-2004 (Fig. 7c). The heat flux with reference to $0^{\circ} \mathrm{C}$ is calculated across the transect shown in Fig. 2. Although the absolute value of this flux is not definitive, as it is calculated on the basis of a reference value and because there is a net volume flux across the transect, its relative temporal variability is here both meaningful and informative because it specifies the relative significance of warm inflow and cold outflow. The interannual trend of the heat flux into $\mathrm{KTr}$, as shown in Fig. 7c, is calculated by filtering monthly mean values with a 12-month-moving average. The heat flux varies significantly with peaks and troughs ranging from $2.8 \mathrm{TW}$ in 1994 to $13 \mathrm{TW}$ in 2003 and back to $3.2 \mathrm{TW}$ in 2007 . This variability is a result of variable air-sea heat exchange as well as variable extent of intrusions of AW onto the shelf. However, the mean annual heat flux was $<5$ TW in 1992-1995 while $>11$ TW in 2003-2004. It then decreased to $<6$ TW in 2005-2008.

Figure 8 shows correlations between volume and heat fluxes into $\mathrm{KTr}$ and atmospheric forcing. The volume flux (positive north, i.e. into KTr) correlates with the wind speed across Denmark Strait at $66.3^{\circ} \mathrm{N}$ (Fig. 8a). Correlation coefficients are $r=0.69$ for winter months (December to March) and $r=0.61$ when all data are included. Heat flux into KTr is strongly correlated with volume flux into KTr (Fig. 8b) ( $r=0.85)$, which is not surprising because the former is calculated from the latter. However, we also find that the volume flux into KTr correlates strongly with along-shore volume flux ( $r=0.74)$ (Fig. 8c). This shows that strong (weak) along-shore transport coincides with low (high) volume and heat fluxes into KTr and this is due to the strong (weak) forcing by coastal winds. Surface atmospheric forcing used to drive the ocean model is illustrated in Fig. 9. In the winter of 1994-1995, northerly winds are persistently strong. These winds cool surface waters and increase the transport of water masses along the coast (Bacon et al., 2008). Cold and fresh waters flow out of $\mathrm{KTr}$ as a result, and this reduces the inflow of AW. The 1994-1995 winter is the winter when the calculated heat flux into KTr is negative from December to March (Fig. 8). Atmospheric conditions are fundamentally different in the winter of 1995-1996 when northerly winds were uncharacteristically and persistently weak (Fig. 9). This change of atmospheric conditions 


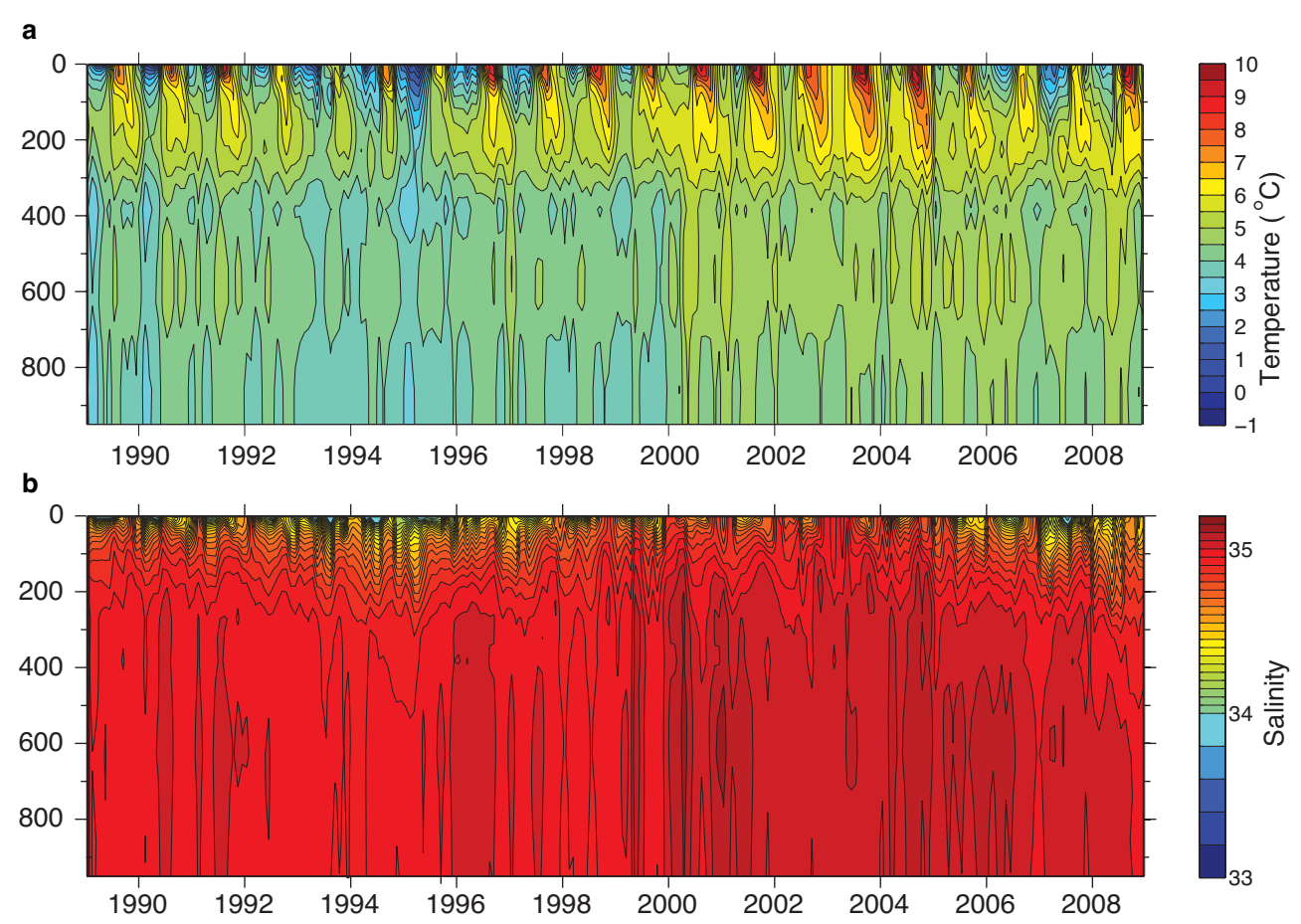

Fig. 5. Hovmøller diagrams showing potential temperature (a) and salinity (b) in ocean reanalysis. The data area-averaged across black box shown in Fig. 1a.

is seen in the meteorological record from Aputiteq where mean winter air temperature (December-March) in 20042005 is $-8.7^{\circ} \mathrm{C}$ compared to $-11.7^{\circ} \mathrm{C}$ in the previous winter (Fig. 4). The ocean model shows that transportation of cold water masses out of $\mathrm{KTr}$ is concurrently reduced while inflow of AW is substantially increased (Fig. 5). Whilst airsea interactions are considerably different in 1995 and 1996, a prolonged warm phase associated with reduced air flow through Denmark Strait occur in 2001-2005. This results in high and persistent inflow of AW at depths of 400-800 m while surface waters warm due to exchange of heat with the atmosphere (Fig. 5). The heat flux directed into KTr in 2003 and 2004 is therefore about threefold that of the early 1990s (Fig. 7c). Cold and relatively strong air flow from northeast re-occur after 2005 and inflows of AW and the heat flux into KTr return to levels similar to those in the early 1990s (Fig. 7c).

\section{The abrupt retreat of KG in 2004-2005}

Figure $7 \mathrm{c}$ shows the calculated heat flux into $\mathrm{KTr}$ as well as mean monthly calving-front position of KG. The front positions are determined from MODIS imagery acquired since 2000, as described by Seale et al. (2011). The time series was extended using previously published data for 1992-2000 (Luckman et al., 2006). An interannual trend is derived by eliminating the seasonal variability and this was done by fil- tering monthly mean positions with a 12-month moving average. This trend is defined by advance of $\sim 1.5 \mathrm{~km}$ in 1992 1995 ; retreat of $\sim 3 \mathrm{~km}$ in 1996-1998; relatively constant positions between 1999 and 2004; and a sudden large retreat of $\sim 7 \mathrm{~km}$ between July 2004 and March 2005, as described in several previous studies (Howat et al., 2007; Joughin et al., 2008a; Luckman et al., 2006; Stearns and Hamilton, 2007; Seale et al., 2011). The glacier re-advanced $\sim 2 \mathrm{~km}$ in 2006-2007 and variation has since been restricted to regular seasonal fluctuations. The large retreat in 2004-2005 is well-documented by MODIS imagery, which shows retreat of $\sim 2.2 \mathrm{~km}$ between 1 July and 14 September, 2004, which was when the latest set of hydrographic data was acquired (Fig. 3). Large amounts of icebergs were present in the fjord during the cruise in 2004 and the MODIS imagery shows that this condition was caused by break-up of the sikussak (a seasonally rigid melange of icebergs, bergy bits and sea ice) in front of KG. Contrary to previous years, recession continued throughout autumn and winter, with the calving front located $6.8 \mathrm{~km}$ inland of the 2004 maximum position on 8 March 2005 (Seale et al., 2011).

The time series of heat flux into KTr and the observed margin position of KG show that the rapid retreat in 2004-2005 occurred about one year after the peak heat flux into KTr in the ocean reanalysis. This delay is comparable to transportation of AW across the shelf, although we do not know how accurately the eddy-permitting model simulates across shelf flows. Nonetheless, the shelf waters including AW were in 

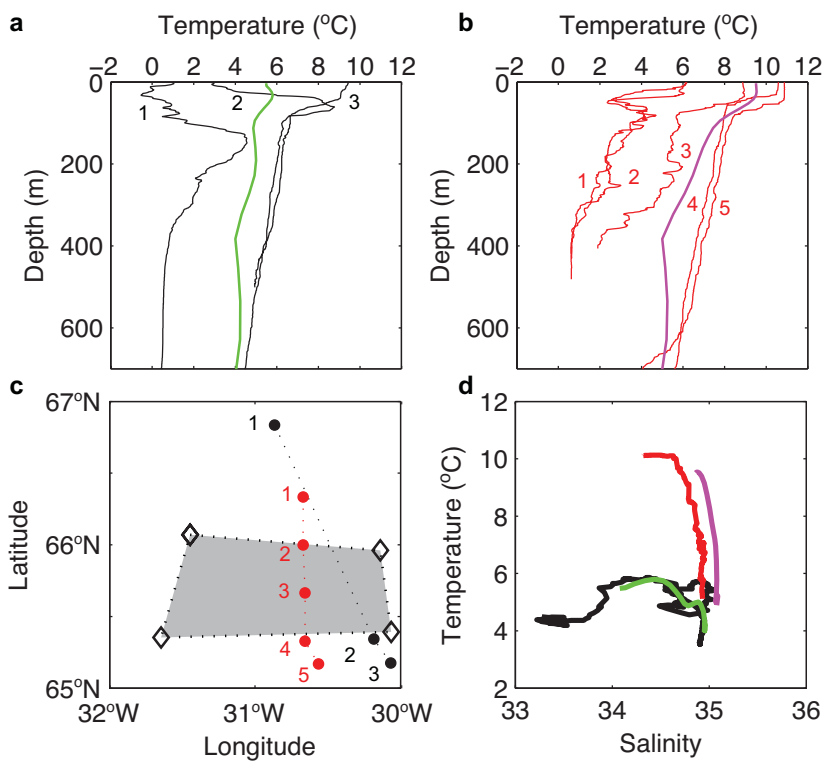

Fig. 6. (a) Temperature profile for September 1993 as seen in ocean reanalysis (green) and observations (black) at the outer continental shelf and slope. Numbers refer to stations whose location is shown in (c). (b) Same as (a) but for September 2004. Ocean reanalysis data are shown by magenta line and red lines are observations. (c) Location diagram with black diamonds and grey shading illustrating area used derive modelled temperature profiles as shown in (a) and (b). The same area is used to derive the water mass properties shown in Figs. 5 and 7. Black dots and dashed line show station transect and location of stations in 1993. Red dots and dashed line show station transect and location of stations in 2004. (d) Potential temperature and salinity for water masses as seen in ocean reanalysis for September 1993 (green) and September 2004 (magenta), and the mean of nearby observations from September 1993 (black) and September 2004 (red).

September 2004 observed to flow at rates up to $20 \mathrm{~cm} \mathrm{~s}^{-1}$ across the station transect shown in Fig. 1a, suggesting the transport of AW from continental slope to fjord is feasible in one year or less. Transport of AW from fjord mouth to glacier termini may require only a few weeks if the circulation of water masses is influenced by intermittent storms, as reported by Straneo et al. (2010) for the similarly sized Sermilik Fjord farther south.

The delayed retreat of $\mathrm{KG}$ relative to peak heat flow into $\mathrm{KTr}$ is similar to the delayed retreat of glaciers farther south relative to peaks seen in sea-surface temperature data (Howat et al., 2008). Howat et al. (2008) suggest the delay is connected to initial slow retreat over topographic high points and subsequent fast retreat across over-deepened troughs with reverse bed slopes. Whereas Helheim Glacier retreated across an over-deepening (Nick et al., 2009), it is not certain that glaciers undergoing significant retreat are necessarily positioned over topographic over-deepenings. The observed delays may in general be connected to the period over which water masses travel from deep ocean, across the continen-
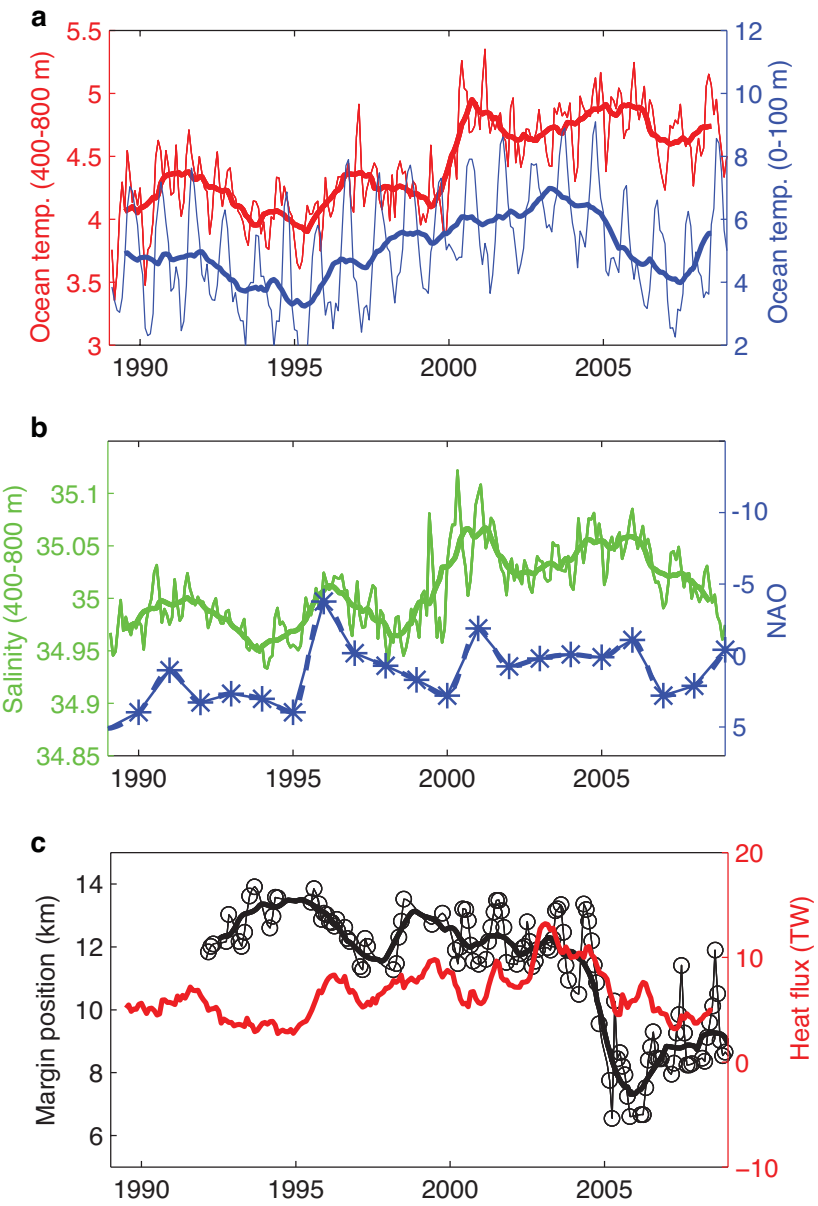

Fig. 7. (a) Time series of potential temperature as shown in Fig. 5, but averaged for 0-100 $\mathrm{m}$ (blue) and 400-800 m (red). Solid bold lines are 12-month-moving averages of monthly mean values. (b) Same as (a), but for salinity at the 400-800 m level (green). Dashed blue line and asterisk show the extended NAO winter index. (c) Monthly margin positions of KG (black circles) derived from satellite imagery as described in text. Black bold line is the 12-month-moving average. The red line is the 12-month-moving average of heat flux calculated at transect shown in Fig. 1a and with reference to $0^{\circ} \mathrm{C}$. The heat flux is positive northward, which is into $\mathrm{KTr}$ and towards the coast.

tal shelf and into fjords, as well as the sensitivity of individual glaciers to oceanographic change. The latter is beyond the scope of this study, but includes the influence of glacier geometry and calving-related processes, such as icefront melting (Rignot et al., 2010) and presence of proglacial ice melange and sikussak (Reeh et al., 2001; Joughin et al., 2008b; Amundson et al., 2010). 

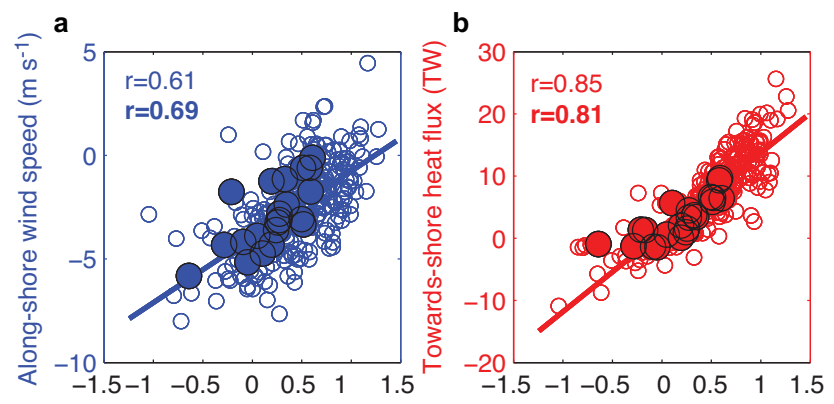

c Towards-shore vol. flux (Sv)
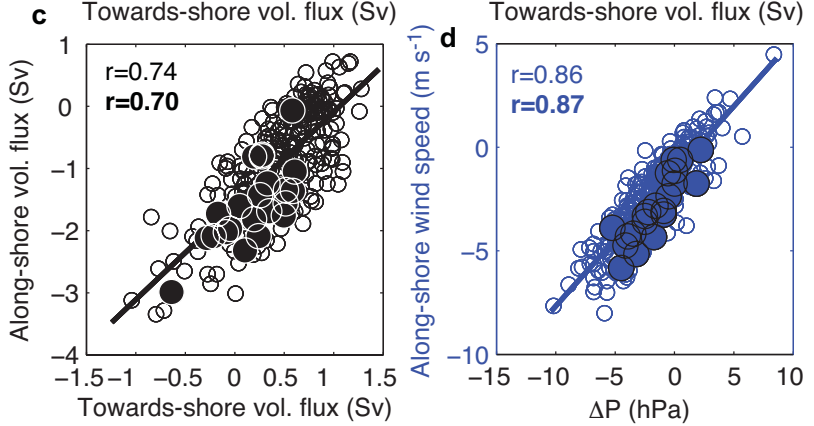

Fig. 8. Correlation plots from ocean reanalysis. (a) Scatter plot of mean monthly volume flux into and out of KTr (yellow line in Fig. 1a) and mean monthly speed of winds crossing Denmark Strait from the north at $66.3^{\circ} \mathrm{N}$. North-flowing waters and wind yield positive values, which means that northerly winds have negative speed while transport into KTr and towards coast is positive. (b) Same as (a), but with towards-shore volume flux compared against towardsshore heat flux calculated with reference to $0^{\circ} \mathrm{C}$. Heat flow is positive towards north, i.e. when it is directed into $\mathrm{KTr}$ and towards the coast. (c) Same as (a) and (b), but with towards-shore volume flux plotted against the along-shore volume flux, i.e. flow of waters crossing the hydrographic transect shown by white line in Fig. 1a. This volume flux is positive when transport is from west to east. (d) Same as (a), but with monthly wind speeds plotted against the Denmark Strait atmospheric pressure gradient, $\Delta P$, derived from meteorological stations in Stykkishólmur and Tasiilaq (see text for details). Open circles and correlation coefficients shown in normal font represent monthly means while data averaged for winters months (December-March) are shown with filled solid circles and bold correlation coefficients.

\section{Synoptic atmospheric forcing}

Our results show that coastal wind forcing in East Greenland is related to the large-scale atmospheric pressure gradient across Denmark Strait. Here, we define the latter, $\Delta P$, as the difference between weather station measurements in Stykkishólmur (Iceland) and Tasiilaq (East Greenland), and its relation to wind forcing is shown in Fig. 8d. There is a strong correlation between $\Delta P$ and wind speed $(r=0.87)$ because the former is a very good indicator of the geostrophic wind, developing from a stationary atmospheric high-pressure system residing over the Greenland Ice Sheet and the Icelandic Low (IL) (Blindheim and Malmberg, 2005; Bacon et al., 2008). The IL is a synoptic pressure system that defines the northern component of the NAO. The geostrophic wind represented by highly negative $\Delta P$ (about $-5 \mathrm{hPa}$ ) is strong and cold, and the air flow follows the coast from the northeast. This wind pattern develops when a deep IL and the stable high pressure over Greenland result in isobars that are nearparallel to the east coast of Greenland (Bacon et al., 2008). Northerly winds are weak when $\Delta P$ approaches or exceeds zero, as it did in 1996 and in the early 2000s, when the IL was positioned differently. The prevailing wind in this setting is warmer and directed towards shore because isobars are perpendicular to the coast. The connection between the large-scale pressure systems and prevailing wind is seen in Fig. 4 as a statistically significant relationship between $\Delta P$ and the mean annual air temperature in Aputiteq $(r=0.64)$. Below, we refer to highly negative values of $\Delta P$ as high $\Delta P$, while values near zero and above are referred to as low $\Delta P$.

The link between $\Delta P$ and the IL is found when the latter is considered to be a "centre of action". Bakalian et al. (2007) used "centres of action", as defined by Hameed et al. (1995), to show that the latitude of the IL influences the frequency of intermittent storms known as tip jets. Adopting the same technique, we determine the latitude and longitude of the IL using monthly mean sea level pressure data in the ERAInterim reanalysis, which cover our period of investigation (Simmons et al., 2006). An area-weighted departure from a sea-level pressure threshold of $1014 \mathrm{mb}$ is in this approach calculated for December to March in a domain that encircles $45^{\circ} \mathrm{N}$ to $70^{\circ} \mathrm{N}$ and $70^{\circ} \mathrm{W}$ to $10^{\circ} \mathrm{E}$. Variations in the latitude and longitude of IL are shown in Fig. 10 together with the NAO winter index (Fig. 10a) and $\Delta P$ (Fig. 10b). The data show a strong statistical correlation between (i) the latitude of IL and the NAO index ( $r=0.78)$, and (ii) the longitude of IL and $\Delta P(r=0.82)$. The first relationship shows that the IL has a northern (southern) position when the NAO index is high (low). The second shows that periods of high (low) $\Delta P$, corresponding to strong (weak) northeasterly air flow in East Greenland, occur when the IL has an eastern (western) position. The eastern position of the IL is over the Irminger Sea southwest of Iceland $\left(\sim 32-35^{\circ} \mathrm{W}\right)$, whereas the western position is over the Labrador Sea closer to Canada ( 39$42^{\circ} \mathrm{W}$ ). Almost identical relationships are found in ERA-40, which is a reanalysis product of the ECMWF covering the period 1958-2002 (Uppala et al., 2005). The correlations are $r \geq 0.99$ when IL positions for the period of overlap (19892002) are compared. Furthermore, the relationships between IL position, NAO index and $\Delta P$ remain statistically significant on the $99 \%$ level when ERA-40 reanalysis data for 1958-1988 are used together with the ERA-Interim reanalysis (1989-present). The relationships are also seen in the NCEP/NCAR reanalysis data (Kalnay et al., 1996) (data not shown), confirming that the interannual variability of the IL as a centre of action can be firmly identified with atmospheric reanalysis data. 

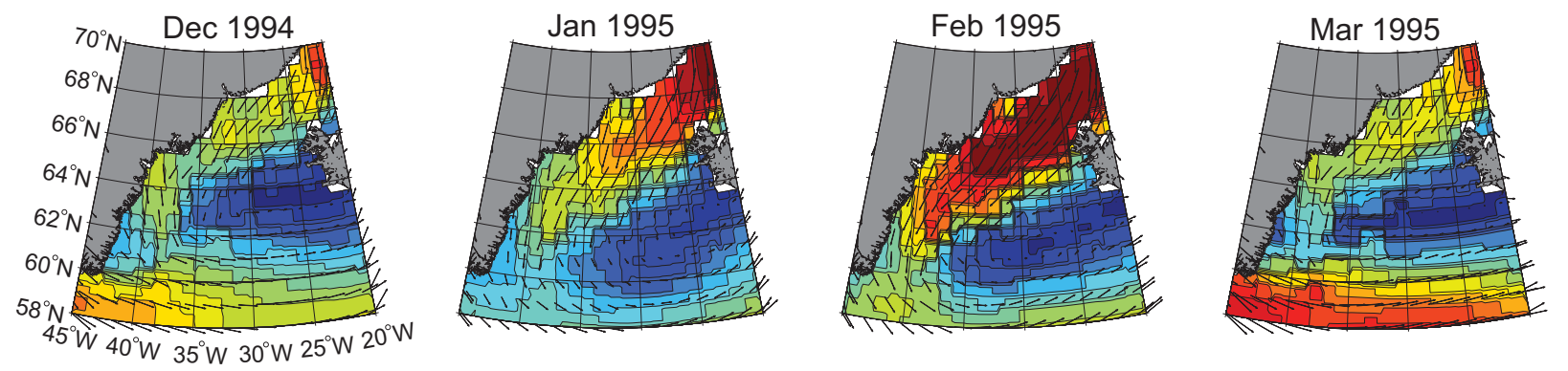

$10 \mathrm{~m} / \mathrm{s}$
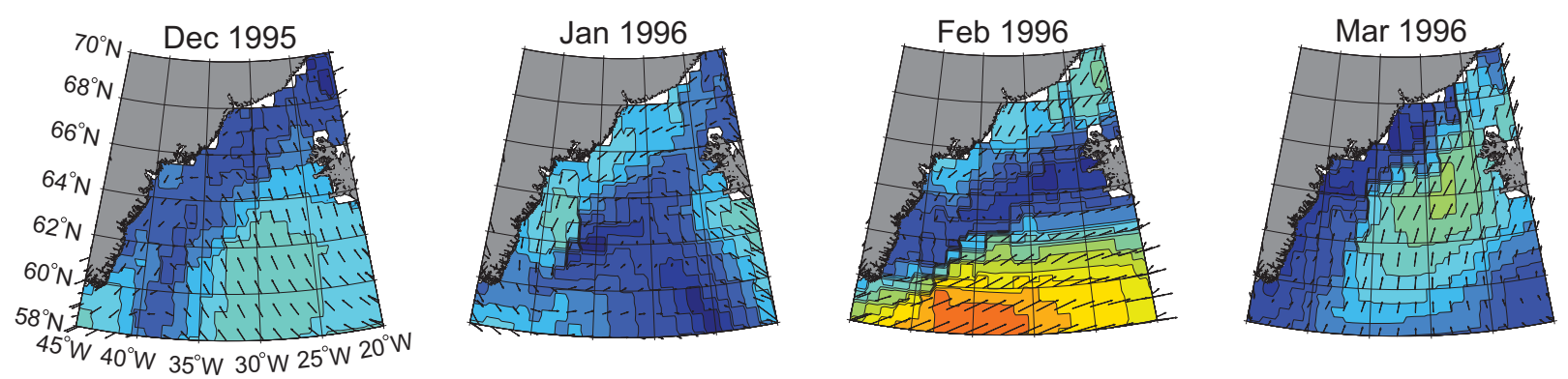

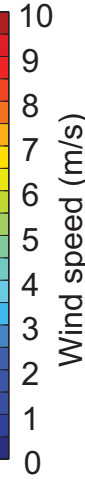

Fig. 9. Maps showing speed and direction of winds near the Denmark Strait during winters in 1994-1995 (top) and 1995-1996 (bottom). The data are from the atmospheric forcing set used to drive the ocean model (see text for details).

\section{Synthesis}

A switch of the IL from $31.6^{\circ} \mathrm{W}$ in the winter of $1994-1995$ to $41.4^{\circ} \mathrm{W}$ in $1995-1996$ (Fig. 10) and the accompanying change of $\Delta P$ from $-4.5 \mathrm{hPa}$ to $+2.2 \mathrm{hPa}$ (Fig. 4) explains the very different wind forcing fields shown in Fig. 9. The switch from strong to weak northeasterly air flow warms the surface layer at $\mathrm{KTr}$, while deeper levels warm from the concurrent higher inflow of AW at depth. Although the ocean reanalysis was produced with assimilation of extensive hydrographic data including the Irminger Sea, constraints from the seasonally ice covered coastal regions are more sparse, so we cannot firmly establish the transportation of AW inside and around fjords. Nonetheless, the warming and cooling of coastal waters seen in the reanalysis at the outer continental shelf is consistent with observations. Holland et al. (2008) show that AW from the Irminger Sea and the east coast warmed coastal waters in West Greenland after 1997 and they suggest that the warming was a result of a the shift in the NAO from a very strong phase in 1992-1995 to a very weak state in 1996. Warming associated with this event is clearly seen in the ocean reanalysis, and we attribute the warming to primarily be a result of the change in $\Delta P$ and the coastal winds. The warming in 1996 may be the cause of substantial thinning of KG by $50 \mathrm{~m}$ at some point between 1993 and 1998 (Thomas et al., 2000). The thinning reported by Thomas et al. (2000) coincides with our observed interannual retreat of $\sim 3 \mathrm{~km}$ in 1995-1998 (Fig. 7c), which is significant because seasonal variability is excluded, although considerably less than the retreat experienced by the glacier in 2004-2005. The larger impact of the latter event is explained in our analysis by sur- face warming as well as a higher inflow of subtropical waters at depth. The concurrent warming of surface waters and the deeper inflows of AW is consistent with the hydrographic data acquired in $\mathrm{KFj}$ in 2004, and both aspects of warming were a result of weak northeasterly air flow associated with low $\Delta P$ and a persistent eastern position of the IL over the Labrador Sea (Fig. 10b).

The wider effect of $\Delta P$ on coastal water temperature and glacier dynamics are shown in Fig. 11. The figure shows changes in the frontal position of 30 marine-terminating glaciers in East Greenland, as reported by Seale et al. (2011). The figure clearly shows that retreats were common in 20002005 for glaciers south of $69^{\circ} \mathrm{N}$ (Fig. 11a), whereas glaciers further north remained largely unchanged (Fig. 11b). The retreat of the southern glaciers coincides with major warming of the entire water column at adjacent coastal sites (Fig. 11c). Furthermore, the connection between $\Delta P$ and water mass change, as discussed above, remains intact when assessed on a regional scale (Fig. 11c). The role of the geostrophic wind and the mechanisms of water mass exchange between the Irminger Sea and KTr thus apply to the shelf seas of East Greenland south of $69^{\circ} \mathrm{N}$, causing impact on outlet glaciers along the entire southeast coast of Greenland. (The lag between $\Delta P$ and coastal water temperatures (illustrated in Fig. 11c by a six month offset) is associated with the rate of water mass transport across the continental shelf.) The setting of glaciers north of $69^{\circ} \mathrm{N}$ is considerably different in that temperatures of coastal waters are largely below $0{ }^{\circ} \mathrm{C}$ (Fig. 11d). The unchanged position of northern glaciers may thus be explained by cold properties of coastal shelf waters (Seale et al., 2011). The cold state of shelf waters north of 

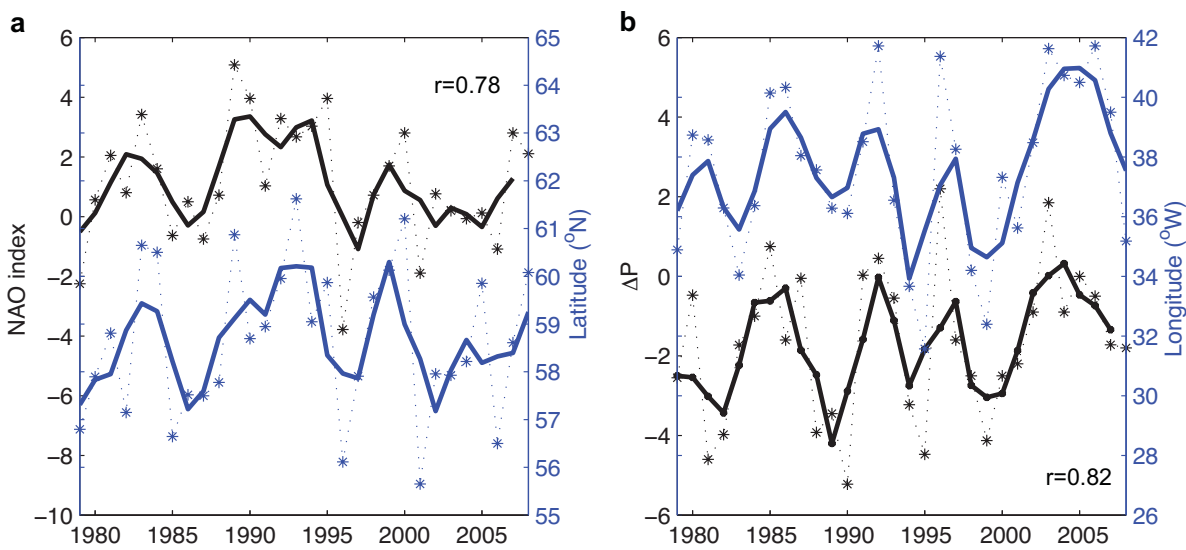

Fig. 10. (a) Plot showing the relationship between the mean latitude of the Icelandic Low (IL) during December-March and the extended (December-March) NAO winter index. (b) Same as (a) but showing the relationship between the longitude of the IL centre and $\Delta P$. Solid lines show the 3-year running means.

Denmark Strait is associated with transport of cold polar waters and sea ice from the Arctic Ocean and a much more limited and distant supply of AW.

\section{Summary and conclusions}

Hydrographic surveys conducted in $\mathrm{KFj}$ and in transects along KTr show warm properties of fjord waters in 2004 relative to 1993. In 1993, we found strongly modified and relatively cold $\left(\sim 1^{\circ} \mathrm{C}\right.$ or less) water with subtropical origin at depths of $280-590 \mathrm{~m}$ near coast and at depths $>350 \mathrm{~m}$ in the central part of the fjord. The subtropical waters extended further into the fjord in 2004 and the waters were less modified, warmer $\left(\sim 1.8^{\circ} \mathrm{C}\right.$ or more $)$ and located $\sim 100 \mathrm{~m}$ higher than in 1993. The surface layer changed from cold $\left(<-1{ }^{\circ} \mathrm{C}\right) \mathrm{PSW}$ in 1993 to much warmer PSWw $\left(>2{ }^{\circ} \mathrm{C}\right)$ in 2004 , consistent with a change in mean air temperature for June-September from $0.90^{\circ} \mathrm{C}$ in 1993 to $2.8^{\circ} \mathrm{C}$ in 2004 . Surface warming and AW inflows at depth are both important. The former may have delayed the onset of seasonal freezeup, whilst promoting continued retreat of $\mathrm{KG}$, as observed (Fig. 7c), due to delayed freeze-up and a subsequently prolonged season with open water and high calving rate. The latter would have influenced KG directly if AW was in direct contact with the calving front, but we cannot confirm this with the available data.

Subtropical waters in an ocean reanalysis are found to seasonally intrude into $\mathrm{KTr}$, a glacially eroded cross-shelf submarine trough extending from $\mathrm{KFj}$ to the continental shelf edge. The intrusions occur mainly in spring and early summer at depths of several hundred meters, and they are driven by winds. Thoma et al. (2008) report similar wind-driven intrusions into a trough carved by glaciers on the Amundsen Sea continental shelf in Antarctica. The oceanic forcing of Greenlandic tidewater glaciers may thus be similar to the oceanic forcing of Antarctic ice streams, although the former glaciers are associated with a much faster response due to their smaller size and steeper terrain (see analysis in Howat et al. (2005) for a comparison). The along-shore volume and freshwater fluxes increase when northerly winds are strong while towards-shore volume and heat fluxes into KTr are reduced or even negative. When northerly winds are weak, surface waters warm due to warmer easterly air flow. Deep waters warm because subtropical waters flow onto the shelf at depths of $>400 \mathrm{~m}$. We calculated the annual heat flux into $\mathrm{KTr}$ and there is significant variations: from $<5$ TW in 19921995 to $>11$ TW in 2003-2004. The heat flux was much reduced in 2005-2008 with values ranging from $4.4 \mathrm{TW}$ to 6.1 TW and this decrease coincides with the stabilisation and partial re-advance of KG in 2005-2008. The hydrographic station data from KTr show transport of water masses across the shelf at rates up to $20 \mathrm{~cm} \mathrm{~s}^{-1}$, suggesting that advection of AW from continental slope to fjord may occur in one year or less. If AW is subsequently flushed through the fjord by the intermediary circulation described by Straneo et al. (2010), KG could be exposed to subtropical AW very effectively. A previously documented episode of thinning in the mid-1990s coincide with observed retreat of KG by $\sim 3 \mathrm{~km}$ and with a sudden warming of waters on the outer shelf in 1996 due to a major shift in the intensity of the NAO. We show that this event caused sudden warming of coastal waters due to a marked change of winds on synoptic scale and that it was a precursor of the larger event in 2004-2005.

The results from this study show that the seasonal and large-scale characteristics of coastal winds are controlling factors in exchange of water masses off the coast of East Greenland. The wind stress on a synoptic scale is defined by the direction and magnitude of isobars associated with semi-permanent atmospheric pressure systems residing over Greenland (high pressure) and near Iceland (low pressure). We found that variations in the longitudinal position of the 

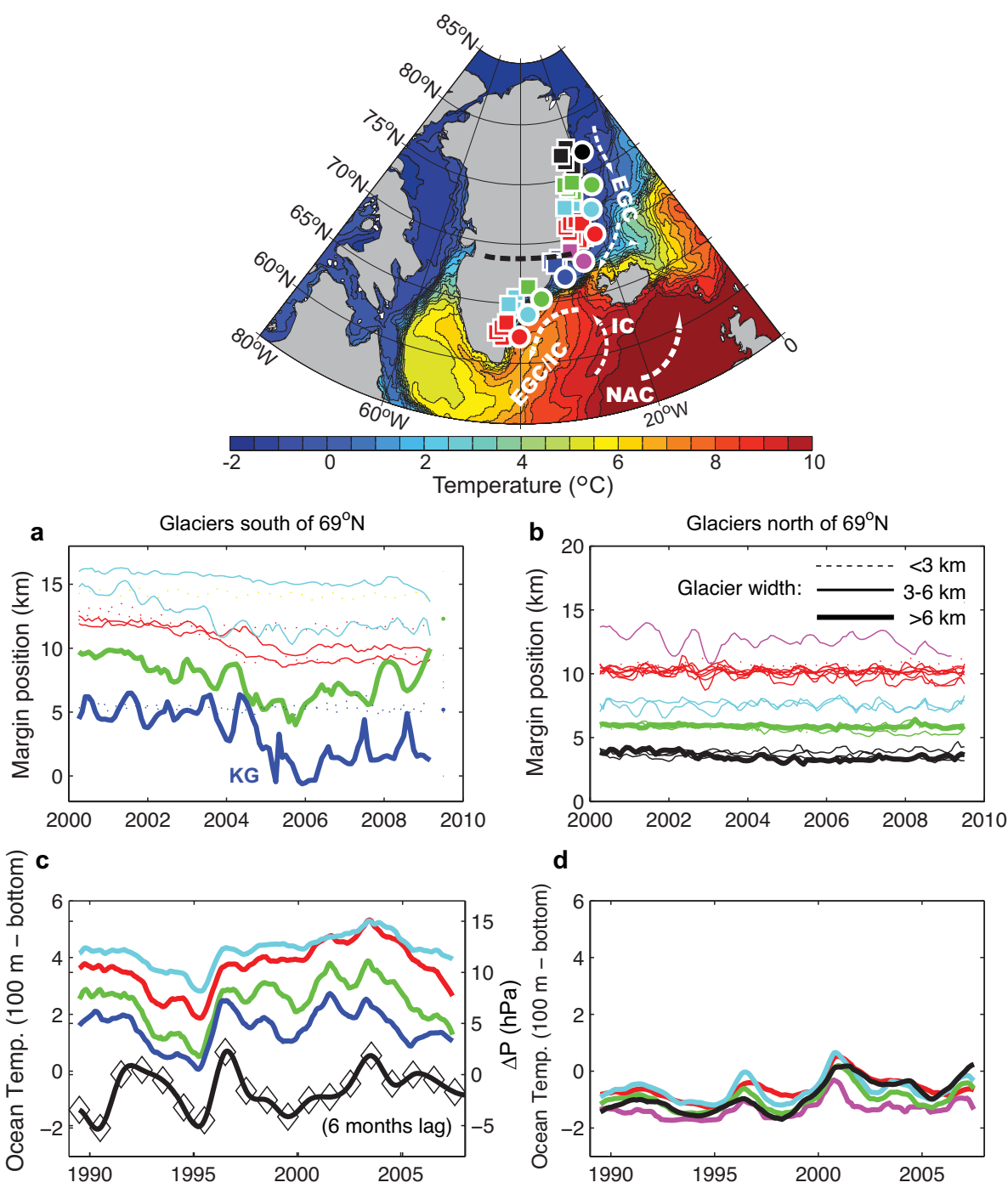

d

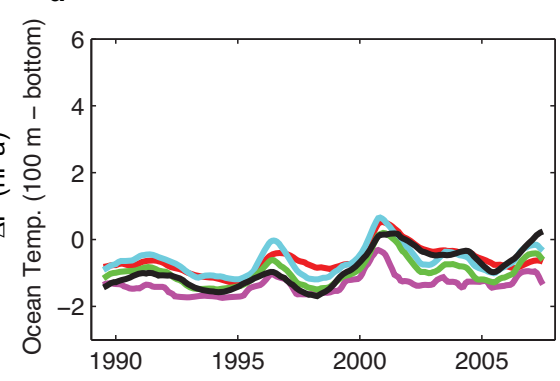

Fig. 11. Map of Greenland and surrounding seas (top) with coloured squares showing locations of marine-terminating glaciers whose frontal positions are shown in (a) and (b). Coloured dots show adjacent locations where subsurface temperatures are examined in ocean reanalysis (c-d). The colour scale show sea surface temperature averaged for 2004. EGC, IC and NAC refer to East Greenland Current, Irminger Current and North Atlantic Current. (a) Changes in the position of calving fronts for glaciers south of $69^{\circ} \mathrm{N}$. The colours represent three glaciers in Mogens Fjord (red), Tingmjarmiut and A. P. Bernstoffs Gletscher (cyan); Helheim Glacier (green), and three glaciers in KFj including KG (blue). (b) Same as (a) but for glaciers north of $69^{\circ} \mathrm{N}$. The glaciers are Borggraven (magenta); eight glaciers in Scoresbysund including Daugaard-Jensen (red); Hisingers and Nordenskjorlds Gletscher near Mestervig (cyan); four glaciers in and around Kejser Franz Joseph Fjord (green), and four glaciers near Danmarkshavn (black). Colours match locations shown on map (top). (c) Subsurface temperature from ocean reanalysis averaged from $100 \mathrm{~m}$ to bottom for sites near glaciers south of $69^{\circ} \mathrm{N}$. Seasonal temperature variations are excluded by filtering the time-series of monthly means with a 12-month-moving average. Colours correspond to those in (a) and locations shown on map (top). Black diamonds and solid black line show winter atmospheric pressure difference across Denmark Strait $(\Delta P)$ as seen in station records from Tasiilaq and Stykkishólmur (see Fig. 1 for location and text for details). (d) Same as (c) but temperature is for sites near northern glaciers. Modified from Seale et al. (2011).

IL explain $67 \%$ of the variability in $\Delta P$, which is the atmospheric pressure gradient that controls the wind stress along the east coast of Greenland. The wind stress is high and from the north when the IL is positioned over the Irminger Sea $\left(\sim 35^{\circ} \mathrm{W}\right)$ and this synoptic setting is associated with cold air temperatures and coastal water masses. The wind stress is low and from the east when the IL is situated over the Labrador Sea $\left(\sim 40^{\circ} \mathrm{W}\right)$ and this synoptic setting is associated with warmer air flow and warming of coastal water masses.

Our findings show that the geostrophic wind should be regarded as a key factor in the oceanographic forcing of the Greenland Ice Sheet. The connection between the position of the IL and $\Delta P$ and its influence on coastal waters apply 
to the shelf seas south of $69^{\circ} \mathrm{N}$, causing impact on outlet glaciers along the entire southeast coast of Greenland. The same mechanism explains the warming observed in coastal waters along the west coast (Holland et al., 2008), as coastal waters from East Greenland are transported to the west coast in coastal currents. Khan et al. (2010) report a shift in the centre of ice-sheet mass losses, from southeast to northwest Greenland after 2007, and these losses may comprise a delayed response of north-western tidewater glaciers to warm coastal waters originating from the east coast.

Acknowledgements. The cruise to KFj in 1993 was funded by the Geological Survey of Canada and the National Science Foundation (USA). The cruise in 2004 was funded by the Natural Environment Research Council (UK). The ocean reanalysis was produced in the IPY ASBO programme funded by the Natural Environment Research Council. We are grateful to the crew and staff on the C. S. S. Hudson (1993) and the James Clark Ross (2004). RM thanks Keith Haines and Greg Smith for their help with the NEMO ocean model.

\section{Edited by: I. M. Howat}

\section{References}

Amundson, J. M., Fahnestock, M. , Truffer, M., Brown, J., Luthi, M. P., and Motyka, R. J.: Ice melange dynamics and implications for terminus stability, Jakobshavn Isbrae Greenland. J. Geophys. Res., 115, F01005, doi:10.1029/2009JF001405, 2010.

AzetsuScott, K. and Tan, F. C.: Oxygen isotope studies from Iceland to an East Greenland Fjord: Behaviour of glacial meltwater plume, Mar. Chem., 56, 239-251, 1997.

Bacon, S., Myers, P. G., Rudels, B., and Sutherland, D. A.: Accessing the inaccessible: Buoyancy-driven coastal currents on the shelves of Greenland and eastern Canada in: Arctic-Subarctic Ocean Fluxes, edited by: Dickson, R. R., Meincke, J., and Rhines, P., Springer, Dordrecht, 703-722, 2008.

Blindheim, J. and Malmberg, S. A.: The mean sea level pressure gradient across the Denmark Strait as an indicator of conditions in the North Icelandic Irminger current, in: The Nordic Seas: An Integrated Perspective, American Geophysical Union, Geophysical Monograph Series, edited by: Drange, H., Dokken, T., Furevik, T., Gerdes, R., and Berger, W., Geoph. Monog. Series, American Geophysical Union, 65-71, 2005.

Box, J. E., Yang, L., Bromwich, D. H., and Bai, L. S.: Greenland Ice Sheet Surface Air Temperature Variability: 1840-2007, J. Climate, 22, 4029-4049, 2009.

Brodeau, L., Barnier, B., Treguier, A. M., Penduff, T., and Gulev, S.: An ERA40-based atmospheric forcing for global ocean circulation models, Ocean Model., 31, 88-104, 2010.

Chen, J. L., Wilson, C. R., and Tapley, B. D.: Satellite gravity measurements confirm accelerated melting of Greenland ice sheet, Science, 313, 1958-1960, doi:10.1126/science.1129007, 2006.

Dowdeswell, J. A., Evans, J., and Ó Cofaigh, C.: Submarine landforms and shallow acoustic stratigraphy of a $400 \mathrm{~km}$-long fjord-shelf-slope-transect, Kangerlussuaq margin, East Greenland, Quat. Sci. Rev., 29, 3359-3369, 2010.
Falina, A., Sarafanov, A., and Sokov, A.: Variability and renewal of Labrador Sea Water in the Irminger Basin in 1991-2004, J. Geophys. Res., 112, C01006, doi:10.1029/2005jc003348, 2007.

Fichefet, T. and Maqueda, M. A. M.: Sensitivity of a global sea ice model to the treatment of ice thermodynamics and dynamics, J. Geophys. Res.-Oceans, 102, 12609-12646, 1997.

Flatau, M. K., Talley, L., and Niiler, P. P.: The North Atlantic Oscillation, surface current velocities, and SST changes in the subpolar North Atlantic, J. Climate, 16, 2355-2369, 2003.

Gemmell, A., Smith, G. C., Haines, K., and Blower, J. D.: Evaluation of water masses in ocean synthesis products, CLIVAR Exchanges, 13, 7-9, 2008.

Gemmell, A., Smith, G. C., Haines, K., and Blower, J. D.: Ocean model-data analyses with Ocean DIVA, Journal of Operational Oceanography, 2, 29-41, 2009.

Goosse, H. and Fichefet, T.: Importance of ice-ocean interactions for the global ocean circulation: A model study, J. Geophys. Res.-Oceans, 104, 23337-23355, 1999.

Haines, K., Blower, J. D., Drecourt, J. P., Liu, C., Vidard, A., Astin, I., and Zhou, X.: Salinity assimilation using S(T): Covariance relationships, Mon. Weather Rev., 134, 759-771, 2006.

Hakkinen, S. and Rhines, P. B.: Decline of subpolar North Atlantic circulation during the 1990s, Science, 304, 555-559, 2004.

Hameed, S., Shi, W., Boyle, J., and Santer, B.: Investigation of the centers of action in the North Atlantic and North Pacific in the ECHAM AMIP simulation, Proceeding of the First International AMIP Scientific Conference, 1995.

Hanna, E., Huybrechts, P., Janssens, I., Cappelen, J., Steffen, K., and Stephens, A.: Runoff and mass balance of the Greenland ice sheet: 1958-2003, J. Geophys. Res.-Atmos, 110, D13108, doi:10.1029/2004jd005641, 2005.

Holland, D. M., Thomas, R. H., de Young, B., Ribergaard, M. H., and Lyberth, B.: Acceleration of Jakoshavn Isbrae triggered by warm susurface ocean waters, Nat. Geosci., 1, 659-664, 2008.

Howat, I. M., Joughin, I., Tulaczyk, S., and Gogineni, S.: Rapid retreat and acceleration of Helheim Glacier, east Greenland, Geophys. Res. Lett., 32, L22502, doi:10.1029/2005GL024737, 2005.

Howat, I. M., Joughin, I., and Scambos, T. A.: Rapid changes in ice discharge from Greenland outlet glaciers, Science, 315, 1559 1561, 2007.

Howat, I. M., Joughin, I., Fahnestock, M., Smith, B. E., and Scambos, T. A.: Synchronous retreat and acceleration of southeast Greenland outlet glaciers 2000-06: ice dynamics and coupling to climate, J. Glaciol., 54, 646-660, 2008.

IPCC: Climate change 2007: The Physical Science Basis. Contributions of Working Group 1 to the Fourth Assessment Report of the Intergovernmental Panel on Climate Change, edited by: Solomon, S., Qin, D., Manning, M., Chen, Z., Marquis, M., Averyt, K. B., Tignor, M., and Miller, H. L., Cambridge University Press, Cambridge, UK, and New York, USA, 996 pp., 2007.

Joughin, I., Howat, I., Alley, R. B., Ekstrom, G., Fahnestock, M., Moon, T., Nettles, M., Truffer, M., and Tsai, V. C.: Icefront variation and tidewater behavior on Helheim and Kangerdlugssuaq Glaciers, Greenland, J. Geophys. Res. 113, F01004, doi:10.1029/2007jf000837, 2008a.

Joughin, I., Howat, I.M., Fahnestock, M., Smith, B., Krabill, W., Alley, R. B., Stern, H., and Truffer, M.: Continued evolution of Jakobshavn Isbræ following its rapid speedup. J. Geophys. Res., 113, F04006, doi:10.1029/2008JF001023, 2008b. 
Kalnay, E., Kanamitsu, M., Kistler, R., Collins, W., Deaven, D., Gandin, L., Iredell, M., Saha, S., White, G., Woollen, J., Zhu, Y., Chelliah, M., Ebisuzaki, W., Higgins, W., Janowiak, J., Mo, K. C., Ropelewski, C., Wang, J., Leetmaa, A., Reynolds, R., Jenne, R., and Joseph, D.: The NCEP/NCAR 40-year reanalysis project, Bull. Am. Meteorol. Soc., 77, 437-471, 1996.

Khan, S. A., Wahr, J., Bevis, M., Velicogna, I., and Kendrick, E.: Spread of ice mass loss into northwest Greenland observed by GRACE and GPS, Geophys. Res. Lett., 37, L06501, doi:10.1029/2010GL042460, 2010.

Large, W. G. and Yeager, S. G.: Diurnal to decadal global forcing for ocean and sea-ice models: The data sets and flux climatologies, Technical Report, TN-460+STR, The National Center for Atmospheric Research, 105 pp., 2004.

Luckman, A., Murray, T., de Lange, R., and Hanna, E.: Rapid and synchronous ice-dynamic changes in East Greenland, Geophys. Res. Lett., 33, L03503, doi:10.1059/2005gl025428, 2006.

Madec, G.: NEMO reference manual, ocean dynamics component: NEMO-OPA., Institut Pierre-Simon Laplace (IPSL), Paris, 2008.

Murray, T., Scharrer, K., James, T. D., Dye, S. R., Hanna, E., Booth, A. D., Selmes, N., Luckman, A., Hughes, A. L. C., and Huybrechts, P.: Ocean-regulation hypothesis for glacier dynamics in south-east Greenland and implications for ice-sheet mass changes. J. Geophys. Res., 115, F03026, doi:10.1029/2009JF001522, 2010.

Reeh, N., Thomsen, H. H., Higgins, A. K., and Weidick, A.: Sea ice and the stability of north and northeast Greenland floating glaciers, Ann. Glaciol., 33, 474-480, 2001.

Rignot, E., Braaten, D., Gogineni, S. P., Krabill, W. B., and McConnell, J. R.: Rapid ice discharge from southeast Greenland glaciers, Geophys. Res. Lett., 31, L10401, doi:10.1029/2004GL019474, 2004.

Rignot, E. and Kanagaratnam, P.: Changes in the velocity structure of the Greenland ice sheet, Science, 311, 986-990, 2006.

Rignot, E., Box, J. E., Burgess, E., and Hanna, E.: Mass balance of the Greenland ice sheet from 1958 to 2007 , Geophys. Res. Lett., 35, L20502, doi:10.1029/2008g1035417, 2008.

Rignot, E., Koppes, M., and Velicogna, I.: Rapid submarine melting of the calving faces of West Greenland glaciers, Nat. Geosci., 3, 187-191, 2010.

Rudels, B., Fahrbach, E., Meincke, J., Budeus, G., and Eriksson, P.: The East Greenland Current and its contribution to the Denmark Strait overflow, ICES J. Mar. Sci., 59, 1133-1154, 2002.

Sarafanov, A., Sokov, A., Demidov, A., and Falina, A.: Warming and salinification of intermediate and deep waters in the Irminger Sea and Iceland Basin in 1997-2006, Geophys. Res. Lett., 34, L23609, doi:10.1029/2007g1031074, 2007.

Sarafanov, A., Falina, A., Mercier, H., Lherminier, P., and Sokov, A.: Recent changes in the Greenland-Scotland overflow-derived water transport inferred from hydrographic observations in the southern Irminger Sea, Geophys. Res. Lett., 36, L13606, doi:10.1029/2009g1038385, 2009.

Seale, A., Christoffersen P., Mugford, R. I., and O'Leary, M.: Ocean forcing of the Greenland Ice Sheet: Calving fronts and patterns of retreat identified by automatic satellite monitoring of eastern outlet glaciers, J. Geophys. Res., 116, F03013, doi:10.1029/2010JF001847, 2011
Shepherd, A., Hubbard, A., Nienow, P., King, M., McMillan, M., and Joughin, I.: Greenland ice sheet motion coupled with daily melting in late summer, Geophys. Res. Lett., 36, L01501, doi:10.1029/2008g1035758, 2009.

Simmons, A., Uppsala, S., Dee, D., and Kobayashi, S.: ERAInterim: New ECMWF reanalysis products from 1989 onwards, European Centre for Medium-Range Weather Forecasts Newsletter, 110, 25-35, 2006.

Smith, G. C., Haines, K., Kanzow, T., and Cunningham, S.: Impact of hydrographic data assimilation on the modelled Atlantic meridional overturning circulation, Ocean Sci., 6, 761774, doi:10.5194/os-6-761-2010, 2010.

Sole, A., Payne, T., Bamber, J., Nienow, P., and Krabill, W.: Testing hypotheses of the cause of peripheral thinning of the Greenland Ice Sheet: is land-terminating ice thinning at anomalously high rates?, The Cryosphere, 2, 205-218, doi:10.5194/tc-2-205-2008, 2008.

Stearns, L. A. and Hamilton, G. S.: Rapid volume loss from two East Greenland outlet glaciers quantified using repeat stereo satellite imagery, Geophys. Res. Lett., 34(5), L05503, doi:10.1029/2006gl028982, 2007.

Straneo, F., Hamilton, G. S., Sutherland, D. A., Stearns, L. A., Davidson, F., Hammill, M. O., Stenson, G. B., and RosingAsvid, A.: Rapid circulation of warm subtropical waters in a major glacial fjord in East Greenland, Nat. Geosci., 3, 182-186, 2010.

Sundal, A. V., Shepherd, A., Nienow, P., Hanna, E., Palmer, S., and Huybrechts, P.: Melt-induced speed-up of Greenland ice sheet offset by efficient subglacial drainage, Nature, 469, 521-524, 2011.

Sutherland, D. A. and Pickart, R. S.: The East Greenland Coastal Current: Structure, variability, and forcing, Prog. Phys Oceanogr., 78, 58-77, 2008.

Syvitski, J. P. M., Andrews, J. T., and Dowdeswell, J. A.: Sediment deposition in an iceberg-dominated glacimarine environment, East Greenland: Basin fill implications, Glob. Planet. Ch., 12, 251-270, 1996.

Thoma, M., Jenkins, A., Holland, D., and Jacobs, S.: Modelling Circumpolar Deep Water intrusions on the Amundsen Sea continental shelf, Antarctica, Geophys. Res. Lett., 35, L18602, doi:10.1029/2008gl034939, 2008.

Thomas, R. H., Abdalati, W., Akins, T. L., Csatho, B. M., Frederick, E. B., Gogineni, S. P., Krabill, W. B., Manizade, S. S., and Rignot, E. J.: Substantial thinning of a major east Greenland outlet glacier, Geophys. Res. Lett., 27, 1291-1294, 2000.

Uppala, S. M., Kallberg, P. W., Simmons, A. J., Andrae, U., Bechtold, V. D., Fiorino, M., Gibson, J. K., Haseler, J., Hernandez, A., Kelly, G. A., Li, X., Onogi, K., Saarinen, S., Sokka, N., Allan, R. P., Andersson, E., Arpe, K., Balmaseda, M. A., Beljaars, A. C. M., Van De Berg, L., Bidlot, J., Bormann, N., Caires, S., Chevallier, F., Dethof, A., Dragosavac, M., Fisher, M., Fuentes, M., Hagemann, S., Holm, E., Hoskins, B. J., Isaksen, L., Janssen, P., Jenne, R., McNally, A. P., Mahfouf, J. F., Morcrette, J. J., Rayner, N. A., Saunders, R. W., Simon, P., Sterl, A., Trenberth, K. E., Untch, A., Vasiljevic, D., Viterbo, P., and Woollen, J.: The ERA-40 re-analysis, Q. J. R. Meteorol. Soc., 131, 2961-3012, 2005 . 
van de Wal, R. S. W., Boot, W., van den Broeke, M. R., Smeets, C. J. P. P., Reijmer, C. H., Donker, J. J. A., and Qoerlemans, J.: Large and rapid melt-induced velocity changes in the Ablation zone of the Greenland Ice Sheet, Science, 321, 111-113, 2008.

van den Broeke, M., Bamber, J., Ettema, J., Rignot, E., Schrama,

E., van de Berg, W. J., van Meijgaard, E., Velicogna, I., and Wouters, B.: Partitioning Recent Greenland Mass Loss, Science, 326, 984-986, 2009.
Velicogna, I. and Wahr, J.: Acceleration of Greenland ice mass loss in spring 2004, Nature, 443, 329-331, 2006.

Yashayaev, I., Bersch, M., and van Aken, H. M.: Spreading of the Labrador Sea Water to the Irminger and Iceland basins, Geophys. Res. Lett., 34, L10602, doi:10.1029/2006g1028999, 2007.

Zwally, H. J., Abdalati, W., Herring, T., Larson, K., Saba, J., and Steffen, K.: Surface melt-induced acceleration of Greenland icesheet flow, Science, 297, 218-222, 2002. 